\title{
Drawing up the macrostructure of a Nguni dictionary, with special reference to isiNdebele
}

\author{
Gilles-Maurice de Schryver \\ Department of African Languages, University of Pretoria, Pretoria 0002, South Africa \\ Research Assistant of the Fund for Scientific Research - Flanders (Belgium) \\ gillesmaurice.deschryver@UGent.be
}

June 2002

\begin{abstract}
In this article a four-step methodology is proposed for the creation of the lemma-sign list of a Nguni-language reference work. The theoretical principles are illustrated throughout with a fullscale case study revolving around isiNdebele. For the suggested approach raw corpus data is utilised, and only standard, straightforward and widely-available software tools are required to process the data. Apart from the inherent value of having an entire macrostructure at one's disposal right from the start of a dictionary project, it is shown how such a list can also be used for both predictions and measurements on lemma-sign, page and time levels. As such, drawing up the macrostructure of a dictionary automatically leads to a 'ruler' with which the entire lexicographic process can successfully be monitored. Specifically for isiNdebele, suggestions are made for the way ahead.
\end{abstract}

\section{Umdzubhulo ${ }^{1}$}

Ukudweba nokwakha ngobubanzi isiHlathululi-mezwi sesiNguni ngokuqalisa elimini lesiNdebele. Kile atikili indlela ezine ziphakanyisiwe zokwakha irhelo lamatshwayo welema lapho kungahlolwa khona umsebenzi welimi lesiNguni. Imileyo yamatiyori ikhonjisiwe ngesilinganiso esipheleleko ngesifundo esizungeze ilimi lesiNdebele. Ngesiphakamiso esivezweko umbiko wekhophasi engakalungiswa isetjenzisiwe, begodu leyo elinganisiweko, nenqophileko nokutholakala ngobubanzi beentlhabagelo zekhompuyutha ziyafuneka ukulungisa nanyana ukudlulisa lombiko. Ngaphandle kokujwayela ukuthola woke umakhiwo ngobubanzi komunye nomunye kusukela ekuthomeni kweprojethi yesiHlathululi-mezwi, kukhombisile bona lelirhelo lingasetjenziswa bunjani ekuqabangeleni nekumedeni amatshwayo welema, ikhasi nezinga lesikhathi. Ngalokho-ke ukudweba umakhiwo ngobubanzi wesiHlathululi-mezwi ngokuzenzakalela kusidosela esimedweni lapho yoke ikambiso ye-lekzikho ingatlhogonyelwa khona ngokuphumelela. Ngokuqalisa esiNdebeleni iimphakamiso sezenzelwe ngaphambili.

\section{Setting South Africa's National Lexicography Units (NLUs) in motion}

Although the Pan South African Language Board (PanSALB) finalised the establishment of a National Lexicography Unit (NLU) for each of South Africa's 9 official African languages in 2000, work at especially the new units has not really come off the ground since then. ${ }^{2}$ This is surprising in the light of a series of pioneering articles published in that same year, articles dealing with both metalexicographic issues (Gouws,
2000), and practical aspects such as corpus-building and corpus-based lexicography (De Schryver \& Prinsloo, 2000a, 2000b and 2000c). These publications were specifically written for and aimed at the prospective lexicographers of the 9 African-language dictionary units.

The first task in any lexicographic endeavour is to decide which items are to be treated in the envisaged dictionary, in other words, to draw up the macrostructure. It is widely accepted today that, on the one hand, 
the actual selection be made with a specific target-user group in mind, and that, on the other hand, the treatment of the items themselves be corpus-based. As several South African languages do not even have a single general-purpose dictionary, the target-user group is in most cases chosen to be as broad as possible, while the corpus is built in such a way that it is of a wide-ranging nature. Even if a corpus cannot immediately be brought together, compilation can still be begun by means of an onomasiological approach to dictionary compilation (cf. e.g. De Schryver \& Lepota, 2001). In an onomasiological approach, selected subject fields are chosen and treated, as compared to a semasiological approach in which one works through the alphabet from A to $\mathrm{Z}$. Once a corpus has been built, the items dealt with in an onomasiological approach may be revisited, and frequency considerations can be utilised to decide what to actually include in a specific dictionary.

\section{Drawing up a dictionary's macrostructure and degrees of conjunctivism}

Even in following an onomasiological approach, it is best, of course, to have a fairly good idea of the nature of the full macrostructure right from the early stages of compilation. Building an electronic corpus, from which the full macrostructure can be derived, thus seems to be the most appropriate first phase in any modern lexicographic project. Ideally, such a corpus should be automatically analysed morphologically, so that the dictionary-citation forms (i.e. the way in which the items appear as lemma signs in a dictionary) are easy to retrieve from the corpus. Unfortunately, apart from the computational tools created by Hurskainen for Kiswahili (cf. e.g. Hurskainen, 1992, 1995, 1996, 1999, Hurskainen \& Halme, 2001), mechanical morphological analysers for the African languages are still being developed. Several human-language technology projects are indeed under way - in Pretoria for isiZulu, isiXhosa and Sesotho sa Leboa, in Harare for ChiShona and SiNdebele - and it is expected that in less than a decade there will be a handful of African-language morphological analysers. As this is not yet the case, investigating the feasibility of drawing up a macrostructure from a 'raw corpus' (i.e. just plain running text without any tags or mark-up whatsoever) is defendable at this stage.
It is not the purpose of this article to re-examine the compilation of (raw) African-language corpora, nor to deal with general aspects regarding the compilation of a dictionary's macrostructure. Rather, in this article we wish to offer true guidance for the creation of the macrostructure of a conjunctively-written African language. In South Africa, conjunctive writing is the case for the languages belonging to the Nguni group, viz. isiZulu, isiXhosa, siSwati and isiNdebele. Although De Schryver and Prinsloo (2000b: 299-302) propose a three-step methodology for the creation of a dictionary's macrostructure, departing from a raw corpus, their approach seems only truly feasible for those African languages for which the degree of conjunctivism is not too high. This is the case for Cilubà, the language by means of which the authors illustrate their approach, and for, for example, the disjunctively-written South African languages, viz, the languages belonging to the Sotho group (Sesotho sa Leboa, Sesotho and Setswana), and Tshivenda and Xitsonga.

We will exemplify our suggested methodology for the creation of the macrostructure of a conjunctivelywritten African language with a case study revolving around isiNdebele. ${ }^{3}$ IsiNdebele being a formerly marginalized language, there is a great need indeed for a scientifically-sound lemma-sign list, a list with which the first isiNdebele dictionaries could finally be compiled. Up to today, not a single general-language dictionary exists with isiNdebele as the source language (Skhosana, 1999: 222). Indeed, so far only isolated efforts resulted in special-purpose lists departing from isiNdebele, such as Mahlangu's (1988) list of 105 Ndebele riddles, or Skosana's (1992) survey of the main divisions of Ndebele culture. IsiNdebele does, however, occur as the target language in some bilingual and multilingual compilations. Examples are Shabangu and Swanepoel's (1989) English to isiNdebele dictionary (a reference work harshly criticised in Skhosana and Wilkes, 2001:26-27), or the (draft) multilingual terminology lists produced by terminologists from the National Language Service (NLS) of the Department of Arts and Culture (DAC) (Alberts, 2000: 236-237). The very first terminology list, with isiNdebele unfortunately again merely as a translation, only saw the light in 2000 (IsiNdebele Language Board, 2000). 


\section{The Pretoria Ndebele Corpus (PNC) and corpus stability tests}

Work on an isiNdebele corpus, the Pretoria Ndebele Corpus (PNC), already started in 1999. The main corpus builder is S.P. Mnguni. Currently, PNC stands at 1 million running words (Prinsloo \& De Schryver, 2002b: 256). If PNC were tagged, each so-called 'word' would have a tag attached to it showing the appropriate 'stem' and ditto grammatical information (its morphological analysis). The stem (+ its extension(s)) is exactly what one needs as dictionary-citation (or canonical) form. In the absence of a morphological analyser for isiNdebele, one way to retrieve all isiNdebele stems from the current PNC would be to manually tag the 1 million words, after which the stems could then be extracted. Given the time required for this drudgery, one can, however, immediately discard this option. The procedure that will be proposed below is to excerpt the 'stems' (+ extensions) from the top frequency 'words'.
In order for this procedure to be valid, however, corpus stability issues need to be taken into account first. Corpus stability for African-language lexicography is discussed in great detail for Sesotho sa Leboa and Xitsonga by Prinsloo and De Schryver (2001). Based on their research, these authors come to the conclusion that well-designed 'general corpora' of 2 million running words, for African languages with the same degree of conjunctivism as Sesotho sa Leboa, can be considered to be 'stable' for both frequent and less frequent items. As the degree of conjunctivism of isiNdebele is roughly twice that of Sesotho sa Leboa (Prinsloo \& De Schryver, 2002b: 261), this implies that valid conclusions can indeed be drawn from a 1million-word isiNdebele corpus.

This claimed stability can be illustrated by means of a comparison of the relative distribution of the alphabetical stretches in the 1-million-word PNC with the corresponding distribution in PNC when only those items occurring at least 5 times are taken into account. The result of this comparison is shown in Table 1.

Table 1 Corpus stability tests on the Pretoria Ndebele Corpus (PNC): Relative distribution of the alphabetical stretches in 'PNC $1 \mathrm{M}$ ' as compared to the corresponding distribution in 'PNC min. freq. $=5$ '

\begin{tabular}{|c|c|c|c|c|c|c|}
\hline & $\begin{array}{l}\text { PNC 1M } \\
\# \text { items }\end{array}$ & $\%$ & $\begin{array}{c}\text { PNC min. freq. }=5 \\
\# \text { items }\end{array}$ & $\%$ & $\begin{array}{l}\text { DIFFERENCE } \\
\text { abs. } \%\end{array}$ & rel. $\%$ \\
\hline $\mathbf{A}$ & 21594 & 11.13 & 2488 & 10.51 & -0.62 & -5.54 \\
\hline B & 13145 & 6.78 & 1151 & 4.86 & -1.91 & -28.21 \\
\hline C & 892 & 0.46 & 72 & 0.30 & -0.16 & -33.82 \\
\hline D & 796 & 0.41 & 102 & 0.43 & +0.02 & +5.06 \\
\hline $\mathbf{E}$ & 15799 & 8.14 & 1925 & 8.14 & -0.01 & -0.11 \\
\hline $\mathbf{F}$ & 641 & 0.33 & 51 & 0.22 & -0.11 & -34.77 \\
\hline $\mathbf{G}$ & 731 & 0.38 & 64 & 0.27 & -0.11 & -28.22 \\
\hline $\mathbf{H}$ & 1283 & 0.66 & 132 & 0.56 & -0.10 & -15.65 \\
\hline I & 14232 & 7.34 & 2275 & 9.61 & +2.28 & +31.06 \\
\hline $\mathbf{J}$ & 408 & 0.21 & 44 & 0.19 & -0.02 & -11.58 \\
\hline $\mathbf{K}$ & 15135 & 7.80 & 1998 & 8.44 & +0.64 & +8.23 \\
\hline $\mathbf{L}$ & 9251 & 4.77 & 1106 & 4.67 & -0.09 & -1.98 \\
\hline $\mathbf{M}$ & 3431 & 1.77 & 532 & 2.25 & +0.48 & +27.13 \\
\hline $\mathbf{N}$ & 32566 & 16.79 & 3684 & 15.57 & -1.22 & -7.25 \\
\hline $\mathbf{O}$ & 6632 & 3.42 & 649 & 2.74 & -0.68 & -19.77 \\
\hline $\mathbf{P}$ & 1028 & 0.53 & 152 & 0.64 & +0.11 & +21.22 \\
\hline $\mathbf{Q}$ & 311 & 0.16 & 34 & 0.14 & -0.02 & -10.37 \\
\hline $\mathbf{R}$ & 839 & 0.43 & 86 & 0.36 & -0.07 & -15.96 \\
\hline $\mathbf{S}$ & 12872 & 6.64 & 1361 & 5.75 & -0.88 & -13.31 \\
\hline $\mathbf{T}$ & 1660 & 0.86 & 236 & 1.00 & +0.14 & +16.56 \\
\hline $\mathbf{U}$ & 21092 & 10.87 & 3134 & 13.24 & +2.37 & +21.82 \\
\hline V & 436 & 0.22 & 54 & 0.23 & +0.00 & +1.54 \\
\hline $\mathbf{W}$ & 7476 & 3.85 & 967 & 4.09 & +0.23 & +6.05 \\
\hline $\mathbf{X}$ & 62 & 0.03 & 4 & 0.02 & -0.02 & -47.11 \\
\hline $\mathbf{Y}$ & 5375 & 2.77 & 730 & 3.09 & +0.31 & +11.35 \\
\hline $\mathbf{Z}$ & 6309 & 3.25 & 631 & 2.67 & -0.59 & -18.00 \\
\hline & 193996 & 100.00 & 23662 & 100.00 & \multicolumn{2}{|c|}{$r=0.981$} \\
\hline
\end{tabular}


The 1-million-word PNC contains exactly $1,033,965$ running words (tokens), and from Column 2 in Table 1 one can see that there are as many as 193,996 different word forms (types) in PNC. On average, every type thus occurs approximately 5 times in the corpus. The relative distribution of those types per alphabetical category is expressed as a percentage in Column 3. This Column 3 shows, for instance, that $7.80 \%$ of the word types in isiNdebele start with the letter K. Column 4 indicates that there are 23,662 types that occur at least 5 times in PNC, while Column 5 shows the relative distribution for these. When only those items with a minimum frequency of 5 are considered, the relative allocation to $\mathrm{K}$ is $8.44 \%$. The absolute difference for $\mathrm{K}$ between the two distributions is thus only $+0.64 \%$, the relative difference $+8.23 \%$. The absolute and relative differences for all alphabetical categories are shown in the last two columns of Table 1. When analysing Columns 3 and 5, one sees that the disparities in frequency between the full corpus and the top-frequency section of the same corpus, are small indeed. This is confirmed by a calculation of the correlation coefficient $r$ between the two distributions, which is as high as 0.981 .

From the above it is thus clear that the isiNdebele corpus of 1 million running words is both large and stable enough to enable conclusions to be drawn from the top frequency section, in this case from all items with a frequency of 5 and above. A different cut-off point could have been chosen, yet it was our aim to end up with a lemma-sign list running into a few thousand items only. Our rationale was that, if the methodology would prove to be feasible, a larger lemma-sign list could be extracted at a later stage. That larger (longer) list would then preferably be extracted from a larger (bigger) corpus. Aiming at a few thousand lemma signs only is defendable taking into account that no generalpurpose dictionaries exist for isiNdebele, combined with the fact that the community needs reference works as soon as possible. As a matter of fact, the current Editor-in-Chief, Mr. P.B. Skhosana, writes in the mission statement of the isiNdebele NLU:

As dictionary making is not an easy short-term process, the Dictionary Unit for isiNdebele does not intend to complete the letters of the alphabet consecutively, but to work on a complete dictionary, increasing the scope and volume as the project continues. This seems to be the best strategy to short-circuit the lengthy period dictionary users will have to wait before the first isiNdebele dictionary becomes available.

(Skhosana, 1999: 223)

The lemma sign list that will be drawn up below, can indeed be considered as the (proposed) macrostructure of the envisaged 'first isiNdebele dictionary'.

\section{Drawing up the macrostructure of a Nguni dictionary: isiNdebele case study}

It was our goal to develop an elegant methodology that would swiftly lead from raw corpus data to a scientifically-sound lemma-sign list. A further objective was to keep the number of steps as low and logi$\mathrm{cal}$ as possible, and to make sure only standard software tools would be required for the process. The proposed methodology was also fully tested on real data and in real time. All in all, just one month was needed to draw up a macrostructure containing 6,000 lemma signs. The actual work was done by P.S. Malebe, who had just joined the isiNdebele NLU.

\section{Step 1 - Extracting top-frequency 'words' from a corpus}

The main aim of the first step is to extract, from a raw corpus of running text, all items (so-called 'words') with a frequency equal to or higher than a chosen threshold. The threshold itself depends on the size of the corpus and the projected length of the resulting macrostructure. For our case study, the 1-million-word PNC was used, and the threshold was set at 5. Extracting the top-frequency items from a raw corpus can be done by means of one simple command with straightforward corpus query software such as for instance WordSmith Tools (Scott, 1999). ${ }^{4}$ To illustrate the output of Step 1, Table 2 displays a random stretch of 25 items starting with the letter S. 
Table 2 Step 1: A random alphabeticallysorted stretch of the top-frequency items in PNC, including the respective frequencies

\begin{tabular}{|lc|}
\hline I (Step 1) & II (Step 1) \\
\hline Item & Freq. \\
\hline siNdebele & 12 \\
Sindeni & 5 \\
sineengcenye & 6 \\
sinemihlobo & 14 \\
sinemisebenzi & 7 \\
sinesiqu & 6 \\
sinesivumelwano & 5 \\
sinezakhi & 8 \\
sineziqu & 8 \\
sing & 8 \\
singa & 18 \\
singaba & 32 \\
singabala & 13 \\
singabi & 8 \\
singabuye & 6 \\
singabuza & 8 \\
singafundiswa & 6 \\
singafuni & 6 \\
singakafiki & 12 \\
singakhamba & 8 \\
singakutjengisa & 9 \\
singakwazi & 5 \\
singalibali & 9 \\
singalibiza & 5 \\
singalitjengisa & 5 \\
\hline
\end{tabular}

As can be seen from Column 4 in Table 1, there are 23,662 items in all as output of this step. Each of those has its own frequency. In Table 2, the different items are headed by $\mathrm{I}$, the corresponding frequencies by II.

\section{Step 2 - Isolating 'dictionary-citation forms'} from each of the top-frequency items

In the second step the main aim is to isolate the 'dictionary-citation forms' from each of the items obtained in Step 1. In view of the ensuing steps, it is advantageous (i) to export Columns I and II to a spreadsheet (such as for instance Microsoft Excel), (ii) to make a copy of Column I, and (iii) to isolate the dictionarycitation forms in that copied column. The outcome of Step 2 is illustrated in Table 3.

Table 3 Step 2: A random sample of the topfrequency items in PNC, each with its dictionary citation form (+prefixes) and its respective frequency

\begin{tabular}{|llr|}
\hline I (Step 1) & I b (Step 2) & II (Step 1$)$ \\
\hline Item & Canonical form + PFs & Freq. \\
\hline siNdebele & -Ndebele si- & 12 \\
Sindeni & -Sindeni & 5 \\
sineengcenye & -ngcenye sinee- & 6 \\
sinemihlobo & -hlobo sinemi- & 14 \\
sinemisebenzi & -sebenzi sinemi- & 7 \\
sinesiqu & -qu sinesi- & 6 \\
sinesivumelwano & -vumelwano sinesi- & 5 \\
sinezakhi & -akhi sinez- & 8 \\
sineziqu & -qu sinezi- & 8 \\
sing & & 8 \\
singa & -nga si- & 18 \\
singaba & -ba singa- & 32 \\
singabala & -bala singa- & 13 \\
singabi & -bi singa- & 8 \\
singabuye & -buye singa- & 6 \\
singabuza & -buza singa- & 8 \\
singafundiswa & -fundiswa singa- & 5 \\
singafuni & -funi singa- & 6 \\
singakafiki & -fiki singaka- \\
singakhamba & -khamba singa- & 5 \\
singakutjengisa & -tjengisa singaku- \\
singakwazi & -azi singakw- & 5 \\
singalibali & -libali singa- & 5 \\
singalibiza & -biza singali- \\
singalitjengisa & -tjengisa singali- & 5 \\
\hline
\end{tabular}

As can be seen from Table 3, it was decided to take away any prefixes (PFs) preceding the stem (whether that stem be a noun stem, verb stem, adjective stem, etc.), but to leave all suffixes (such as verbal extensions, etc.) agglutinated to the stem. Between the two extremes for the lemmatisation of African languages, viz. the 'word' tradition versus the 'stem' tradition, there are indeed numerous possible and valid 'hybrid' 
approaches. It is, however, not the purpose of this article to re-open the debate on word versus stem lemmatisation strategies (see for a critical analysis Van Wyk, 1995). The actual choice for one strategy over the other, or even for a hybrid approach, is left to each of the NLU's discretion. That choice is often merely based on tradition, and for isiNdebele this means that existing dictionaries for isiZulu are likely to be used as examples. In the approach illustrated in Table 3 we thus basically followed the stem tradition, in that the dictionary-citation forms are to be found under the first letter of the stem, whether or not that stem be followed by suffixes.

From Table 3 it can be deduced that not all topfrequency words result in a dictionary-citation form. Actually, the original list of 23,662 items generated
22,076 canonical forms + PFs. Top-frequency 'words' that were left blank in Column I $\mathrm{b}$ include single letters, Roman numerals, foreign proper nouns, and English words.

Step 3 - Bringing together equal dictionarycitation forms as well as their corresponding frequencies

The main aim of the third step is to bring all dictionary-citation forms that are equal, as well as their corresponding frequencies, together. In a spreadsheet this can easily be achieved by sorting on Column I b. Once copies of Columns I b and II are made, a random section of B-initial canonical forms is as shown in Table 4.

Table 4 Step 3a: A random sample of B-initial dictionary-citation forms, each with its respective frequency - intermediate phase

\begin{tabular}{|c|c|c|c|c|}
\hline I (Step 1) & I b (Step 2) & I c (Step 3) & I (Step 1) & II b (Step 3) \\
\hline Item & Canonical form + PFs & Canonical form + PFs & Freq. & Freq. \\
\hline banzi & -banzi & -banzi & 55 & 55 \\
\hline abanzi & -banzi a- & -banzi a- & 8 & 8 \\
\hline elibanzi & -banzi eli- & -banzi eli- & 11 & 11 \\
\hline kabanzi & -banzi ka- & -banzi ka- & 43 & 43 \\
\hline libanzi & -banzi li- & -banzi li- & 8 & 8 \\
\hline obanzi & -banzi o- & -banzi o- & 5 & 5 \\
\hline ububanzi & -banzi ubu- & -banzi ubu- & 7 & 7 \\
\hline uBaphelile & -Baphelile u- & -Baphelile u- & 14 & 14 \\
\hline uBaqedeni & -Baqedeni u- & -Baqedeni u- & 6 & 6 \\
\hline ubasa & -basa u- & -basa u- & 7 & 7 \\
\hline ukubasa & -basa uku- & -basa uku- & 10 & 10 \\
\hline wabasa & -basa wa- & -basa wa- & 10 & 10 \\
\hline babase & -base ba- & -base ba- & 7 & 7 \\
\hline sibase & -base si- & -base si- & 5 & 5 \\
\hline ubasele & -basele u- & -basele u- & 14 & 14 \\
\hline kubaswe & -baswe ku- & -baswe ku- & 5 & 5 \\
\hline amabatha & -batha ama- & -batha ama- & 21 & 21 \\
\hline kuBathabile & -Bathabile ku- & -Bathabile ku- & 35 & 35 \\
\hline lakaBathabile & -Bathabile laka- & -Bathabile laka- & 27 & 27 \\
\hline ngoBathabile & -Bathabile ngo- & -Bathabile ngo- & 5 & 5 \\
\hline nguBathabile & -Bathabile ngu- & -Bathabile ngu- & 14 & 14 \\
\hline noBathabile & -Bathabile no- & -Bathabile no- & 21 & 21 \\
\hline sakaBathabile & -Bathabile saka- & -Bathabile saka- & 5 & 5 \\
\hline uBathabile & -Bathabile u- & -Bathabile u- & 429 & 429 \\
\hline
\end{tabular}


From Columns I b and I $\mathrm{c}$ in Table 4, one can clearly see that all instances of each dictionary citation form are brought together. It is now a simple matter to mark all equal canonical forms, and to replace them with just one canonical form - this phase is illustrated graphically with the boxes in Column I c of Table 4. Likewise, all corresponding frequencies can be marked this phase is illustrated graphically with the boxes in Column II b of Table 4. Spreadsheet software can obviously be asked to automatically calculate the sums for the boxes in Column II b. The result of collapsing the boxed information is shown in Table 5 .

If one sums all frequencies in Column II (or Column II b) of the entire resulting list, one arrives at a total frequency of 693,781 . This simply means that the top-frequency items constitute 693,781 of the
$1,033,965$ running words in the entire PNC. Formulated differently, by only utilising those items with a frequency of at least 5 , or thus by only analysing $2 \%$ of all running words $(23,662$ out of $1,033,965)$, two thirds $(67 \%)$ of the entire corpus is effectively covered.

\section{Step 4 - Adding frequency bands to the lemma-sign list}

In the fourth and final step, the main aim is to break up the obtained lemma-sign list into frequency bands. The most influential scientific publication in this regard is doubtless Kilgarriff's (1997) 'Putting Frequencies in the Dictionary', which is an account of how the top 3,000 lemma signs were marked in Summers' $\left(1995^{3}\right)$ Longman Dictionary of Contemporary English, Third

Table 5 Step 3b: A random sample of B-initial dictionary-citation forms, each with its respective frequency - final phase

\begin{tabular}{|c|c|c|c|c|}
\hline I (Step 1) & I b (Step 2) & I c (Step 3) & II (Step 1) & II b (Step 3) \\
\hline Item & Canonical form + PFs & Canonical form & Freq. & Freq. \\
\hline banzi & -banzi & -banzi & 55 & 137 \\
\hline abanzi & -banzi a- & & 8 & \\
\hline elibanzi & -banzi eli- & & 11 & \\
\hline kabanzi & -banzi ka- & & 43 & \\
\hline libanzi & -banzi li- & & 8 & \\
\hline obanzi & -banzi o- & & 5 & \\
\hline ububanzi & -banzi ubu- & & 7 & \\
\hline uBaphelile & -Baphelile u- & -Baphelile & 14 & 14 \\
\hline uBaqedeni & -Baqedeni u- & -Baqedeni & 6 & 6 \\
\hline ubasa & -basa u- & -basa & 7 & 27 \\
\hline ukubasa & -basa uku- & & 10 & \\
\hline wabasa & -basa wa- & & 10 & \\
\hline babase & -base ba- & -base & 7 & 12 \\
\hline sibase & -base si- & & 5 & \\
\hline ubasele & -basele u- & -basele & 14 & 14 \\
\hline kubaswe & -baswe ku- & -baswe & 5 & 5 \\
\hline amabatha & -batha ama- & -batha & 21 & 21 \\
\hline kuBathabile & -Bathabile ku- & -Bathabile & 35 & 536 \\
\hline lakaBathabile & -Bathabile laka- & & 27 & \\
\hline ngoBathabile & -Bathabile ngo- & & 5 & \\
\hline nguBathabile & -Bathabile ngu- & & 14 & \\
\hline noBathabile & -Bathabile no- & & 21 & \\
\hline sakaBathabile & -Bathabile saka- & & 5 & \\
\hline uBathabile & -Bathabile u- & & 429 & \\
\hline
\end{tabular}


Edition (LDOCE3). According to the author ' $[\mathrm{t}] \mathrm{h}$ task is essentially very simple: - take a corpus, · extract a frequency list, [...] - identify the [...] cut-off points, . mark the corresponding dictionary entries accordingly' (Kilgarriff, 1997: 136). If one sorts the data in Table 5 on Column II b in decreasing order as 'primary sort', and on Column I $c$ in alphabetical order as 'secondary sort', then it is indeed an easy matter to identify the cut-off points and to mark the canonical forms accordingly. We chose to mark the top 500 lemma signs with a (1), the next 500 with a (2) and the third band of 500 with a (3). The result of this straightforward task is illustrated in Table 6.

Table 6 Step 4a: Adding frequency bands to the lemma-sign list - intermediate phase

\begin{tabular}{|lclc|}
\hline III (Step 4) & & I c (Step 3) & II b (Step 3) \\
\hline N & Freq. band & Canonical form & Freq. \\
\hline 1 & 1 & -thi & 17724 \\
2 & 1 & -bona & 15546 \\
3 & 1 & -nye & 10277 \\
4 & 1 & -ke & 8129 \\
5 & 1 & -ntu & 8027 \\
6 & 1 & -tjho & 7185 \\
7 & 1 & -khe & 7047 \\
8 & 1 & -bonyana & 6679 \\
$\ldots$ & $\ldots$ & $\ldots$ & $\ldots$ \\
497 & 1 & -saba & 255 \\
498 & 1 & -jarimani & 252 \\
499 & 1 & -ntambama & 251 \\
500 & 1 & -nqopho & 250 \\
501 & 2 & -khuphe & 249 \\
502 & 2 & -raga & 249 \\
503 & 2 & -ngathana & 248 \\
504 & 2 & -pheze & 248 \\
$\ldots$ & $\ldots$ & $\ldots$ & $\ldots$ \\
1494 & 3 & -pho & 53 \\
1495 & 3 & -thandazo & 53 \\
1496 & 3 & -Tjhabangu & 53 \\
1497 & 3 & -tlhago & 53 \\
1498 & 3 & -ahlukaniswe & 52 \\
1499 & 3 & -felani & 52 \\
1500 & 3 & -gijime & 52 \\
\hline
\end{tabular}

In order to obtain the end product, Column I c can be sorted alphabetically. This will throw up the sought lemma-sign list, together with the corresponding frequency band for each canonical form. It should be kept in mind that the latter is derived from the sum of each instance of that particular canonical form for which the frequency is at least 5 in a million words. A random section of the resulting lemma-sign list can be seen in Table 7.

Table 7 Step 4b: Adding frequency bands to the lemma-sign list - final phase

\begin{tabular}{|c|c|c|}
\hline \multirow{2}{*}{$\begin{array}{l}\text { III (Step 4) } \\
\text { Freq. band }\end{array}$} & I c (Step 3) & II b (Step 3) \\
\hline & Canonical form & Freq. \\
\hline \multirow[t]{8}{*}{2} & -banzi & 137 \\
\hline & -Baphelile & 14 \\
\hline & -Baqedeni & 6 \\
\hline & -basa & 27 \\
\hline & -base & 12 \\
\hline & -basele & 14 \\
\hline & -baswe & 5 \\
\hline & -batha & 21 \\
\hline \multirow[t]{2}{*}{1} & -Bathabile & 536 \\
\hline & -Batjeleni & 28 \\
\hline \multirow[t]{2}{*}{1} & -bawa & 726 \\
\hline & -bawako & 5 \\
\hline \multirow[t]{2}{*}{3} & -bawe & 67 \\
\hline & -bawiwa & 6 \\
\hline 3 & -bawo & 79 \\
\hline \multirow[t]{3}{*}{2} & -baya & 113 \\
\hline & -bayaneni & 6 \\
\hline & -bayede & 27 \\
\hline \multirow[t]{4}{*}{3} & -bayeni & 82 \\
\hline & -bayethe & 12 \\
\hline & -bayibayi & 7 \\
\hline & -bazwa & 6 \\
\hline \multirow[t]{2}{*}{1} & -be & 4527 \\
\hline & -bebhe & 7 \\
\hline 1 & -begodu & 1459 \\
\hline
\end{tabular}

The resulting lemma-sign list consists of 5,980 canonical forms. Exactly 1,500 of them, or thus one quarter, has been given a frequency marker, while the remaining three quarters have not been supplied with a frequency indication. Columns III and I $\mathrm{c}$ in Table 7 
effectively constitute the first-ever fully corpus-based macrostructure for isiNdebele. As such, the potential of this product is hardly imaginable.

\section{The way ahead for the National Lexicography Units: isiNdebele case study}

Taken at face value, it is of course laudable that a rather sizeable macrostructure for a conjunctivelywritten African language can be created in just one month's time. Yet, from the moment a dictionary unit has such a lemma-sign list at its disposal, one has much more than just a lemma-sign list. This will be illustrated below.

\section{Monolingual, bilingual and bilingualised dictionaries, and more ...}

Firstly, it should be clear that the resulting macrostructure can be used for the compilation of both mono- and bilingual dictionaries. The next logical step seems to be to import the resulting list from the spreadsheet into a database, such as for instance Microsoft Access. A virtually unlimited number of fields can be added in a database to each canonical form. Thus, for instance, one can now add a column for the parts of speech (POSs) of each lemma sign. One only needs to do this in one language, upon which that column can be copied for all lemma signs, and with search and replace, the equivalent POSs in the other language can be created automatically. Other fields can subsequently be filled with pronunciation information, definitions, translation equivalents, examples, translations of examples, etc. - and this for every sense of each canonical form.

As a result of the database structure, selected fields can be chosen for any type of dictionary. If one wishes to produce the first-ever general monolingual dictionary for isiNdebele, one will only extract the monolingual data. It goes without saying that the software can be instructed to present the frequency band in one way, the lemma signs in a certain typeface, the POSs in yet another typeface, the definitions in this or that way, etc. Conversely, say one wishes to produce a bilingual dictionary, then one can simply extract the isiNdebele data on the one hand, and the translations on the other. Even bilingualised (also called 'semi-bilingual') dictionaries, thus reference works showing characteristics of both monolingual and bilingual dic- tionaries (cf. e.g. Laufer \& Melamed, 1994), can be produced from the same database.

In case one would be interested in compiling a bidirectional bilingual isiNdebele-English dictionary, one could for instance make use of the lemmatised frequency list for the 6,318 English lemma signs with more than 800 occurrences in the whole 100 -millionword British National Corpus (BNC). ${ }^{5}$ This macrostructure for English has been posted on the Internet by Kilgarriff (1996), and was prepared in the same way as the LDOCE3 list. Note that the size of this English list is of the same order of magnitude as the size of the list derived above for isiNdebele. Both lists are roughly 6,000 items long, which means that they are indeed ideal to form the basis of the macrostructure of each side of a potential bidirectional bilingual isiNdebele-English dictionary. In order to honour the reversibility principle (cf. e.g. Tomaszczyk, 1988: 290, Gouws, 1989:162, Gouws, 1996:80), both the isiNdebele and English macrostructures will out of necessity grow larger. Indeed, the reversibility principle is the condition whereby all lexical items presented as lemma signs or translation equivalents in the $\mathrm{X}-\mathrm{Y}$ section of a dictionary are respectively translation equivalents and lemma signs in the $\mathrm{Y}-\mathrm{X}$ section of the dictionary.

In short, the macrostructure that was drawn up for isiNdebele can be used as the backbone of a database which can be populated with a multitude of information slots, upon which a variety of dictionaries can be printed or even consulted electronically. The latter is a given as databases are the best format in which to store electronic dictionaries. The database fields can of course also be exported to a word processor such as Microsoft Word or Corel WordPerfect for further processing.

\section{Dictionary compilation}

Secondly, when it comes to the actual dictionary compilation, the 6,000-items-strong isiNdebele lemma-sign list has a number of other advantages. It stands to reason that the items themselves are not just any items; instead, they are the most representative canonical forms of the isiNdebele language. Furthermore, since each of those items occurs at least 5 times in the current corpus, this implies by definition that at least 5 instances, and thus at least 5 concordance lines, can be generated for each dictionary-citation form by corpus 
query software. This is ideal to assist the lexicographers active within the isiNdebele NLU. Indeed, definitions can be based on those concordance lines, the lines themselves can be used to select or adapt suitable examples from, and appropriate translation equivalents might also be gleaned by looking at screen-fulls of authentic occurrences.

Furthermore, the different steps used in the creation of the final list are obviously still available and contain crucial extra data. Comparing Column I $b$ with Column I c in Table 5, for instance, immediately tells the lexicographer which prefixes typically occur with any given lemma sign. This information could be the first step towards the inclusion of an Extra Column with grammatical information, an innovation pioneered by the first CoBulld dictionary (Sinclair, 1987). Evidently, a thorough study would need more additional facts, such as information on typical collocations, frequent clusters, characteristic patterns, etc. - all of which can be retrieved with the help of corpus query software such as WordSmith Tools.

\section{Planning and management}

Thirdly and finally, having the full macrostructure of a dictionary at one's disposal right from the start of a lexicographic project, allows for a rather precise planning of the entire undertaking. On a general level, the full lemma-sign list undeniably gives a good idea of the relative distribution of the different alphabetical stretches in the final dictionary (compare in this regard Prinsloo and De Schryver, 2002a). In Column 2 of Table 8 the number of lemma signs per alphabetical category is listed, and the same information is expressed as a percentage in the last column.

Table 8 Multidimensional predictions on lemma, page and time level for an isiNdebele dictionary

\begin{tabular}{|c|c|c|c|c|c|}
\hline & $\begin{array}{c}\text { Lemmas } \\
\text { (sum: } 5980 \text { lemmas) }\end{array}$ & $\begin{array}{c}\text { Pages } \\
\text { (aim: } \mathbf{3 5 0} \text { pages) }\end{array}$ & $\begin{array}{c}\text { Time } \\
\text { in days } \\
\text { (aim: } 2 \text { years) }\end{array}$ & $\begin{array}{c}\text { week \# } \\
\text { (aim: } 104 \text { weeks) }\end{array}$ & $\%$ \\
\hline $\mathbf{A}$ & 92 & 5.4 & 8.0 & 2 & 1.54 \\
\hline B & 504 & 29.5 & 43.9 & 10 & 8.43 \\
\hline C & 68 & 4.0 & 5.9 & 12 & 1.14 \\
\hline D & 248 & 14.5 & 21.6 & 16 & 4.15 \\
\hline $\mathbf{E}$ & 87 & 5.1 & 7.6 & 17 & 1.45 \\
\hline $\mathbf{F}$ & 209 & 12.2 & 18.2 & 21 & 3.49 \\
\hline G & 167 & 9.8 & 14.5 & 24 & 2.79 \\
\hline H & 270 & 15.8 & 23.5 & 29 & 4.52 \\
\hline I & 23 & 1.3 & 2.0 & 29 & 0.38 \\
\hline $\mathbf{J}$ & 79 & 4.6 & 6.9 & 30 & 1.32 \\
\hline $\mathbf{K}$ & 547 & 32.0 & 47.7 & 40 & 9.15 \\
\hline $\mathbf{L}$ & 374 & 21.9 & 32.6 & 46 & 6.25 \\
\hline M & 454 & 26.6 & 39.6 & 54 & 7.59 \\
\hline $\mathbf{N}$ & 683 & 40.0 & 59.5 & 66 & 11.42 \\
\hline 0 & 27 & 1.6 & 2.4 & 67 & 0.45 \\
\hline $\mathbf{P}$ & 369 & 21.6 & 32.1 & 73 & 6.17 \\
\hline $\mathbf{Q}$ & 136 & 8.0 & 11.8 & 76 & 2.27 \\
\hline $\mathbf{R}$ & 220 & 12.9 & 19.2 & 79 & 3.68 \\
\hline $\mathrm{S}$ & 333 & 19.5 & 29.0 & 85 & 5.57 \\
\hline $\mathbf{T}$ & 672 & 39.3 & 58.5 & 97 & 11.24 \\
\hline $\mathbf{U}$ & 5 & 0.3 & 0.4 & 97 & 0.08 \\
\hline V & 169 & 9.9 & 14.7 & 100 & 2.83 \\
\hline w & 27 & 1.6 & 2.4 & 100 & 0.45 \\
\hline $\mathbf{X}$ & 8 & 0.5 & 0.7 & 101 & 0.13 \\
\hline $\mathbf{Y}$ & 55 & 3.2 & 4.8 & 102 & 0.92 \\
\hline $\mathbf{z}$ & 154 & 9.0 & 13.4 & 104 & 2.58 \\
\hline & 5980 & 350 & 521 & & 100.00 \\
\hline
\end{tabular}


A graphical visualisation of the relative distribution of the alphabetical categories is shown in Figure 1 , where the height of each bar indicates the number of lemma signs per stretch.

The breakdown as a percentage, Column 6 in Table 8 , can now also be used to predict the number of pages required for each alphabetical stretch, and even to suggest the time needed for the completion of each section of the dictionary.

It is realistic to assume that the central text of the first isiNdebele dictionary to be produced will be targeted to contain roughly 350 pages. The percentages in the last column of Table 8 enable the prediction of the number of pages per alphabetical category. The result is shown numerically in Column 3 of Table 8, and graphically in Figure 2.

From Figure 2 it is clear that we have arrived at a very powerful tool indeed, as the lexicographers now have a true 'ruler' - with which the pages could indeed be physically measured - at their disposal.

If it is assumed that two years can be devoted to the actual compilation of the central text (at 5 working days a week, that is $\mathbf{5 2 1}$ days under ideal circumstances), then the number of days required per alphabetical category is as shown in Column 4 of Table 8 . If compilation is done from $\mathrm{A}$ to $\mathrm{Z}$ and if one focuses on the week number in which a certain letter is completed, cf. Column 5 of Table 8 , then the projected progress through the alphabet is as shown in Figure 3.

Figure 1 Relative distribution of the lemma signs in an isiNdebele dictionary (sum: 5,980 lemmas)

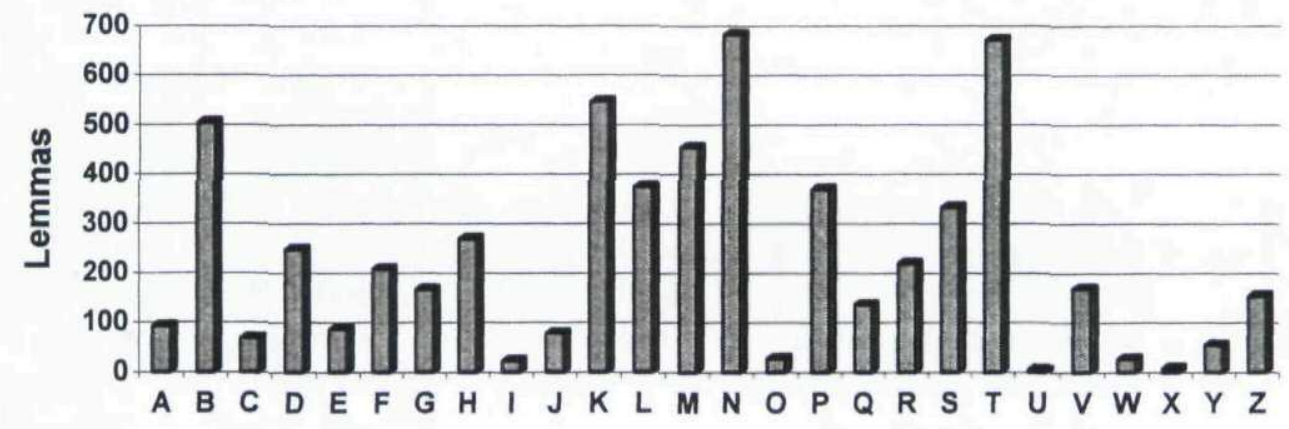

Figure 2 IsiNdebele "ruler": Number of pages per alphabetical category (aim: 350 pages)

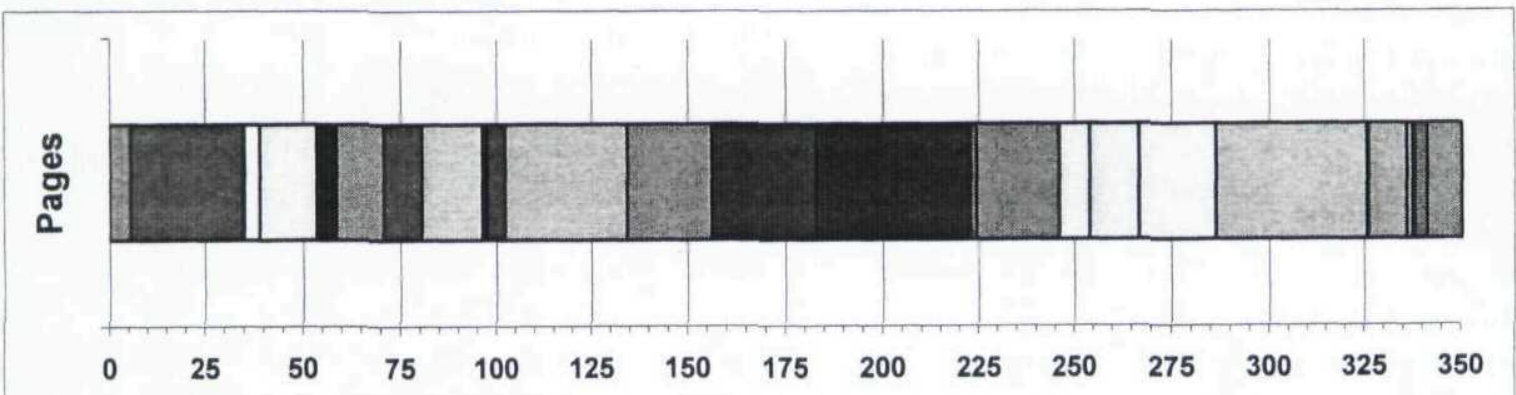

पA 
Figure 3 Projected progress through the alphabet for an isiNdebele dictionary (aim: 2 years, or 104 weeks)

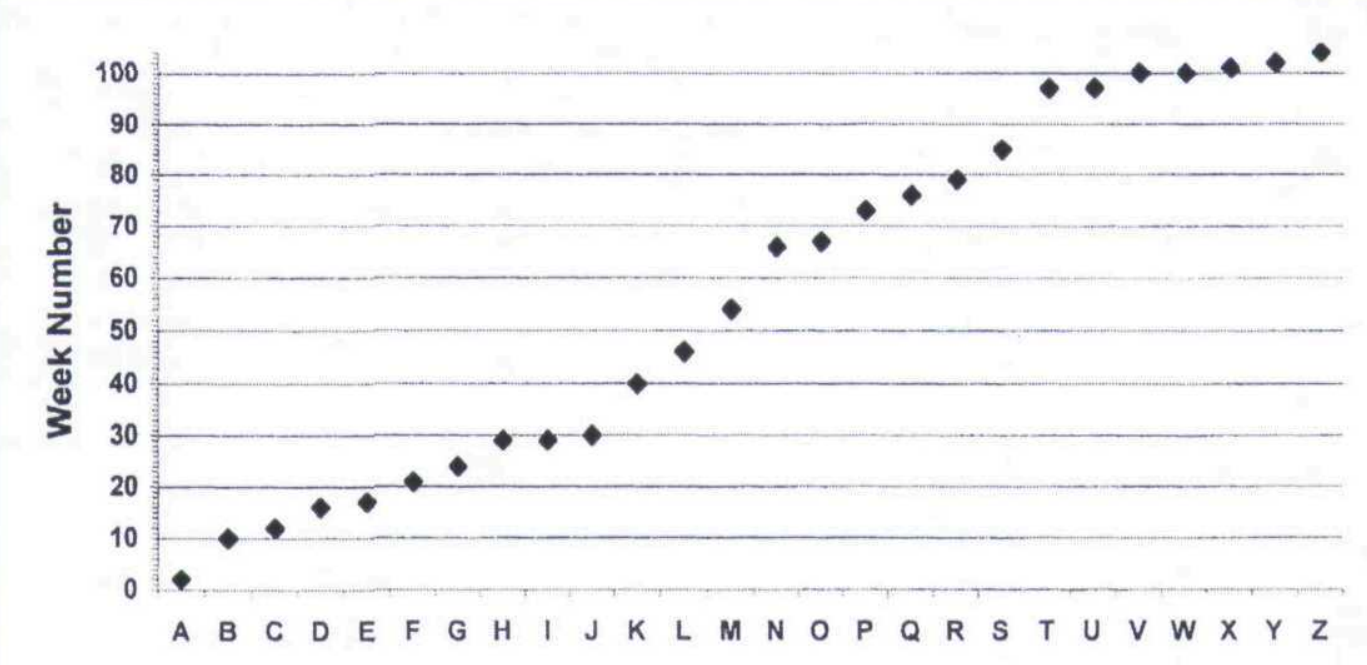

In Figure 3 each mark corresponds with the completion of a particular alphabetical category in a certain week.

It should be apparent that an Editor-in-Chief who has access to Figures 1,2 and 3 (and the corresponding detailed values of Table 8), can indeed effectively plan and envisage the work entailed. It should be pointed out, however, that the completion of a dictionary necessitates more than the central text. Front and back matters should also be written, it may be necessary to collect extra data or even to carry out original fieldwork, and it might be decided to send team members to linguistics or lexicography conferences. Nonetheless, even a quick glance at the values in Table 8 will immediately indicate, for instance, that 504 lemma signs need to be treated under the category B, that 29.5 pages will be required to do so, and that roughly 44 working days should be spent on the compilation. In case the dictionary is written by going through the alphabet from $A$ to $Z$ (which is of course not a necessity!), then Table 8 also shows that the B section will be completed in the 10th week.

Further statistics, especially relevant for the pro- duction of paper dictionaries, can even be calculated. Since 5,980 lemma signs are to be entered in all, on 350 pages, this means that an average of 17 articles should appear on each single dictionary page. If every page further has two columns of 35 lines each, this implies that every article should on average be 4 column-lines long.

All in all, assigning the work evenly to various compilers (compare in this regard Landau, 2001:362) and monitoring the entire compilation process, is made possible thanks to the creation, right from the start, of just one list: the macrostructure.

\section{In conclusion}

In this article we have shown clearly that it is feasible to draw up the macrostructure of a Nguni-language dictionary in just four easy steps. The suggested methodology departs from a raw corpus and only requires standard, straightforward and widely-available software tools. In Step 1 top-frequency words are extracted from a corpus of running text. This step can be performed with versatile corpus query software such as WordSmith Tools. In Step 2 the dictionary-citation 
forms are isolated from each of the top-frequency items; in Step 3 the dictionary-citation forms that are equal as well as their corresponding frequencies are brought together; and in Step 4 frequency bands are added to the lemma-sign list. Steps 2 to 4 can easily be performed with spreadsheet software such as Microsoft Excel. The four-step methodology was tested on real data and in real time, and the results indicate that the creation of the macrostructure of a desk-sized dictionary for a conjunctively-written African language need not take more than a month's work.

As case study, we opted for the creation of a macrostructure for isiNdebele - a language badly in need of a scientifically-sound lemma-sign list. Apart from the generic potential of the four-step methodology, the fact that such a list is now available for the very first time for isiNdebele, holds unprecedented promises. Indeed, the availability - right from the early stages of a lexicographic project - of a complete lemmasign list of a projected reference work, enables the planning of an entire dictionary on a multitude of levels, viz. as regards the number of lemma signs, the number of pages, and the compilation time per alphabetical category. On a managerial level, the macrostructure can be used as a 'ruler' with both prediction and measurement power. Indeed, not only can work be assigned evenly to the various compilers (prediction), but the compilers' performance can now also be computed precisely (measurement).

We also made suggestions as to how to proceed from here. A transfer of the macrostructure to a database was suggested, and it was indicated that one single database can hold various types of dictionaries simultaneously. Populating database fields with a wide range of microstructural elements will enable any National Lexicography Unit to produce the dictionaries their communities are waiting for. A smooth yet sound methodology to do so has now become available for all African languages, whether these languages are written disjunctively or conjunctively.

\section{Notes}

1 Thanks are due to P.J. Masilela and P.S. Malebe for the help with the isiNdebele abstract.

2 Since this article is being submitted for publica- tion in a South African journal, necessary sensitivity with regard to the term 'Bantu' languages is exercised in our choice rather to use the term African languages. Keep in mind, however, that the latter includes more than just the 'Bantu Language Family'.

3 IsiNdebele is also known as Southern Ndebele (or even Southern Transvaal Ndebele), and differs from SiNdebele (i.e. Zimbabwean Ndebele). IsiNdebele comprises the dialects isiNala and isiNzunza, and according to Wilkes (1997: 75): 'IsiNdebele, as it is officially known, is a Nguni language spoken by roughly 600000 people of whom the majority reside in KwaNdebele, the so-called Ndebele homeland situated in the northwestern part of Mpumalanga, not very far from Pretoria and close to the borders of the Northern and North-West provinces respectively.'

4 For more information on WordSmith Tools, we would like to refer the reader to the Home Page of Mike Scott, the creator of the software:

$<$ http://www.lexically.net> (or else: $<$ http://www.liv.ac.uk/ ms2928>).

5 Only slight adaptations would be required in order to also cover items that are unique to South African English.

\section{References}

Alberts, M. 2000. Terminology management at the National Language Service. Lexikos 10 (AFRILEXreeks/series 10: 2000):234-251.

De Schryver, G-M. \& Lepota, B. 2001. The lexicographic treatment of days in Sepedi, or When mother-tongue intuition fails. Lexikos 11 (AFRILEX-reeks/series 11: 2001):1-37.

De Schryver, G-M. \& Prinsloo, D.J. 2000a. The compilation of electronic corpora, with special reference to the African languages. Southern African Linguistics and Applied Language Studies 18(1-4):89106.

De Schryver, G.-M. \& Prinsloo, D.J. 2000b. Electronic corpora as a basis for the compilation of African-language dictionaries, Part 1: The macrostructure. South African Journal of African Languages 20(4):291-309. 
De Schryver, G-M. \& Prinsloo, D.J. 2000c. Electronic corpora as a basis for the compilation of Africanlanguage dictionaries, Part 2: The microstructure. South African Journal of African Languages 20(4):310-330.

Gouws, R.H. 1989. Leksikografie. Pretoria: Academica. Gouws, R.H. 1996. Idioms and collocations in bilingual dictionaries and their Afrikaans translation equivalents. Lexicographica, International Annual for Lexicography 12:54-88.

Gouws, R.H. 2000. Toward the formulation of a metalexicographic founded model for National Lexicography Units in South Africa, in Wörterbücher in der Diskussion IV. Vorträge aus dem Heidelberger Lexikographischen Kolloquium (Lexicographica Series Maior 100), edited by H.E. Wiegand. Tübingen: Max Niemeyer Verlag:109-133.

Hurskainen, A. 1992. A two-level computer formalism for the analysis of Bantu morphology. An application to Swahili. Nordic Journal of African Studies 1(1):87-122.

Hurskainen, A. 1995. Information retrieval and twodirectional word formation. Nordic Journal of African Studies 4(2):81-92.

Hurskainen, A. 1996. Disambiguation of morphological analysis in Bantu languages. In COLING-96. The 16th International Conference on Computational Linguistics, Center for Sprogteknologi, Copenhagen, Denmark, August 5-9, 1996. Proceedings, Vol. 1:568-573.

Hurskainen, A. 1999. SALAMA. Swahili Language Manager. Nordic Journal of African Studies 8(2): 139-157.

Hurskainen, A. \& Halme, R. 2001. Mapping between disjoining and conjoining writing systems in Bantu languages: Implementation on Kwanyama. Nordic Journal of African Studies 10(3):399-414.

IsiNdebele Language Board. 2000. IsiNdebele Terminology and Orthography No. 1/IsiNdebele Itheminoloji Netlolo-Magama Yoku-1. Pretoria: Government Printer.

Kilgarriff, A. 1996. BNC database and word frequency lists. Available from:

$<\mathrm{ftp}$ ://ftp.itri.bton.ac.uk/bnc/>.

Kilgarriff, A. 1997. Putting frequencies in the dictio- nary. International Journal of Lexicography 10(2):135-155.

Landau, S.I. 2001. Dictionaries: The art and craft of lexicography. 2nd edition. Cambridge: Cambridge University Press.

Laufer, B. \& Melamed, L. 1994. Monolingual, bilingual and 'bilingualised' dictionaries: Which are more effective, for what and for whom?, in Euralex 1994 Proceedings, Papers submitted to the 6th EURALEX International Congress on Lexicography in Amsterdam, The Netherlands, edited by W. Martin, W. Meijs, M. Moerland, E. ten Pas, P.GJ. van Sterkenburg, \& P. Vossen. Amsterdam: Vrije Universiteit:565-576.

Mahlangu, D.M. 1988. Imiraro: Ndebele riddles. South African Journal of African Languages 8 (Supplement 1):147-172.

Prinsloo, D.J. \& De Schryver, G-M. 2001. Monitoring the stability of a growing organic corpus, with special reference to Sepedi and Xitsonga. Dictionaries: Journal of The Dictionary Society of North America 22:85-129.

Prinsloo, D.J. \& De Schryver, G-M. 2002a. Designing a measurement instrument for the relative length of alphabetical stretches in dictionaries, with special reference to Afrikaans and English, in Proceedings of the Tenth EURALEX International Congress, EURALEX 2002, Copenhagen, Denmark, 13-17 August 2002, edited by A. Braasch \& C. Povlsen. Copenhagen: Center for Sprogteknologi, Københavns Universitet:483-494.

Prinsloo, D.J. \& De Schryver, G.-M. 2002b. Towards an $11 \times 11$ array for the degree of conjunctivism/ disjunctivism of the South African languages. Nordic Journal of African Studies 11(2):249-265.

Scott, M. 1999. WordSmith Tools version 3. Oxford: Oxford University Press. See for this software also: $<$ http://www.lexically.net/wordsmith/index.html>.

Shabangu, T.M. \& Swanepoel, J.J. 1989. Isihlathululimezwi. An English-South Ndebele dictionary. Cape Town: Maskew Miller Longman.

Sinclair, J.M. ed. 1987. Collins COBUILD English Language Dictionary. London: HarperCollins Publishers.

Skhosana, P.B. 1999. Dictionary unit for IsiNdebele. 
Lexikos 9 (AFRILEX-reeks/series 9: 1999): 222-224. Also available from:

$<$ http://www.sun.ac.za/wat/translex/FINAALA2. html>.

Skhosana, P.B. \& Wilkes, A. 2001. Umlando Wokutlolwa KwesiNdebele [Writing System of IsiNdebele]. Pretoria: University of Pretoria.

Skosana, N.E. 1992. Dzubhula Ngesilulwini [Help Yourself from the Grain-store]. Pietermaritzburg: Centaur Publications.

Summers, D. director. 19953. Longman dictionary of contemporary English. 3rd edition. Harlow: Longman Dictionaries.
Tomaszczyk, J. 1988. The bilingual dictionary under review, in ZüriLEX'86 Proceedings, Papers read at the EURALEX International Congress, University of Zürich, 9-14 September 1986, edited by M. Snell-Hornby. Tübingen: A. Francke Verlag:289 297.

Van Wyk, E.B. 1995. Linguistic assumptions and lexicographical traditions in the African languages. Lexikos 5 (AFRILEX-reeks/series 5B: 1995):8296.

Wilkes, A. 1997. Language contact and language change - the case of Southern Transvaal Ndebele. South African Journal of African Languages 17(2):75-80. 